\title{
Association between Levels of Total Cell-Free DNA and Development of Preeclampsia-A Literature Review
}

\author{
Shi Wu Wen, MB, MSc, PhD ${ }^{8}$ Mark Walker, MD, MSc, FRCSC $3,4,9$ \\ 1 OMNI Research Group, Ottawa Hospital Research Institute, Ottawa, Canada \\ ${ }^{2}$ Department of Prenatal Diagnosis Centre, Shanghai JiaoTong \\ University, International Peace Maternity and Child Health Hospital, \\ School of Medicine, Shanghai, China \\ 3 OHRI, Ottawa Hospital Research Institute, Clinical Epidemiology \\ Program, Ottawa, Canada \\ ${ }^{4}$ Division of Maternal-Fetal Medicine, Department of Obstetrics, \\ Gynecology and Newborn Care, The Ottawa Hospital, Ottawa, Canada \\ ${ }^{5}$ Department of Obstetrics, Shanghai JiaoTong University, \\ International Peace Maternity and Child Health Hospital, School of \\ Medicine, Shanghai, China \\ ${ }^{6}$ Better Outcomes and Registry Network, Ottawa, Canada \\ ${ }^{7}$ CHEO, Children's Hospital of Eastern Ontario, Ottawa, Canada \\ ${ }^{8}$ Department of Epidemiology and Community Medicine, University \\ of Ottawa, Ottawa, Canada \\ ${ }^{9}$ Canadian Institutes of Health Research, Ottawa, Canada
}

Yi Wu, PhD $1,2,3$ Ana Werlang, $\mathrm{MD}^{4}$ Weiwei Cheng, $\mathrm{PhD}^{5}$ Andrea Lanes, MSc, $\mathrm{PhD}^{6,7}$

Address for correspondence Mark Walker, MD, MSc, FRCSC, Department of Obstetrics, Gynecology and Newborn Care, The Ottawa Hospital-General Campus, 501 Smyth Road, Room 8488, Box 804, Ottawa, Ontario K1H-8L6, Canada (e-mail: mwalker@toh.ca).

Am J Perinatol Rep 2021;11:e38-e48.

\begin{abstract}
Keywords

- cell-free DNA

- preeclampsia

- cfDNA

- pregnancy

Objectives The aim of the study is to synthesize the evidence and evaluate the total cell-free deoxyribonucleic (cfDNA) associated with the prediction of preeclampsia (PE). Total cfDNA is constituted by both cell-free fetal DNA (cffDNA) originated mainly from the placenta, and maternal cfDNA derived from maternal leukocytes.

Methods A systematic review was conducted by searching PubMed and Medline. Literature reporting levels of total cfDNA in the development of PE was included. Studies that only reported cffDNA, but no cfDNA concentrations were not included in this review.

Results Eight studies were included. Seven reported values of cfDNA in PE patients, regardless of early or late onset $P E$, six of which demonstrated a significant increase of cfDNA in patients who subsequently developed PE. Seven studies evaluated cfDNA levels in the first trimester, six of which showed significant increase of cfDNA concentrations in women who later developed PE. Five studies investigated cfDNA levels in the second trimester, all presenting increased total cfDNA levels in the PE group compared with normal controls.

Conclusion Total cfDNA may play a role as a biochemical marker of PE, compared with fetal cfDNA. Large prospective studies with homogeneous populations and standardized methodology are needed to further confirm its predictive value.
\end{abstract}

received

December 12, 2018

accepted after revision

April 24, 2020
DOI https://doi.org/

$10.1055 / \mathrm{s}-0040-1721674$

ISSN 2157-6998.

\footnotetext{
(c) 2021. The Author(s).

This is an open access article published by Thieme under the terms of the Creative Commons Attribution-NonDerivative-NonCommercial-License, permitting copying and reproduction so long as the original work is given appropriate credit. Contents may not be used for commercial purposes, or adapted, remixed, transformed or built upon. (https://creativecommons.org/ licenses/by-nc-nd/4.0/)

Thieme Medical Publishers, Inc., 333 Seventh Avenue, 18th Floor, New York, NY 10001, USA
} 
Preeclampsia (PE) is a pregnancy complication characterized by the onset of hypertension and proteinuria after 20 weeks of gestation. ${ }^{1}$ PE affects approximately 5 to $9 \%$ of pregnancies worldwide and accounts for 10 to $15 \%$ of maternal death globally. ${ }^{2,3}$ Its etiology is multifactorial and prophylactic intervention before the clinical onset of the disease is the key to reduce maternal and fetal morbidity and mortality. ${ }^{4}$ According to recent research conducted in this field, biochemical markers such as placental growth factor have been found to perform well in early identifying women at high risk of developing PE. ${ }^{5}$ Biochemical markers reflective of placental insufficiency have become effective tools in identifying women at risk of adverse pregnancy outcomes.

Recent studies suggest that genetic markers may have a role on PE prediction. ${ }^{6-9}$ Total cell-free deoxyribonucleic (cfDNA) was described in 1997, and it is constituted by both cell-free fetal DNA (cffDNA) derived mainly from the placenta, and maternal cfDNA originates from maternal leukocytes. ${ }^{10}$ Since then, the possibility of using genetic markers to screen for fetal diseases has been explored. cfDNA was described as a marker of ischemia by Miranda et $\mathrm{al}^{11}$ when a gradual and strong relationship between cfDNA levels and the severity of PE was observed, with the highest levels corresponding to those patients with HELLP syndrome. Thus, cfDNA levels, both fetal and total, may represent a biomarker probably related to the aforementioned placental ischemia. ${ }^{11}$

Based on this data, we searched for evidence investigating the association between the levels of total cfDNA and PE. This study was designed to systematically review the literature and investigate the association between cfDNA levels and the association with the subsequent development of PE.

\section{Study Design}

\section{Data Sources and Search Strategy}

A protocol with defined objectives, criteria for study selection, and quality assessment of included literature was developed. Covidence online software (from https://www. covidence.org, on October 31, 2018) was used to screen titles and abstracts. We conducted a literature search of research indexed in PubMed and Medline from 1997 to 2019 using a various combination of keywords: total cfDNA, cffDNA, maternal cfDNA, PE, and adverse pregnancy outcome.

\section{Study Selection}

The inclusion criteria were as follows: (1) studies that reported cfDNA levels with or without cffDNA levels in maternal plasma/serum in PE patients; (2) studies that collected maternal blood samples before the clinical onset of PE; (3) studies that included a comparison group of normal pregnancy; and (4) studies that reported the association between cfDNA levels and PE. Studies that only reported cffDNA but no cfDNA concentrations were excluded. Additionally, reviews, editorials, and letters to editors were excluded.

\section{Assessment of Quality}

The quality of the included articles was assessed using the Grading of Recommendations Assessment, Development, and Evaluation (GRADE) system, which has been adopted by the Society for Maternal-Fetal Medicine. ${ }^{12}$

\section{Data Extraction and Synthesis}

The baseline characteristics of the eight studies are summarized in - Table 1. This includes cfDNA analyzing methodology, marker utilized, gestational age (GA) when samples were collected, case and control sample sizes, median and interquartile ranges of cfDNA levels, and $p$-value for each subgroup. The studies included in this systematic review were published between 2004 and 2017. Two of the studies were conducted in South Korea, one in the United States, and five were done in Europe. Of the eight studies included in this systematic review, two were retrospective case-control studies and six were prospective case-control. In total, there were 377 cases of PE and 2,525 controls. Cases were defined as patients who developed PE and compared with healthy patients. Results were reported as mean and standard deviation, being $p<0.05$ statistically significant.

\section{Results}

The literature and article selection process are presented in -Fig. 1. A total of 206 articles were identified in PubMed and Medline through title and abstract screening. Once 99 duplicates were removed, 107 studies remained. The papers were reviewed by title and abstract by two independent investigators (Y.W. and W.C.). Based on the study selection criteria, eight papers were eligible for a full-text review. ${ }^{13-20}$ We listed all the excluded studies by category in Appendix 1. Each study was reviewed in detail and assessed for quality. All included literature was determined to be low quality received " $C$ " due to the observational nature of the investigations ( - Table 2 ).

Demographic variables were listed in - Table 3. No studies showed significant difference between maternal age and PE. Three out of eight studies found a correlation between increased body mass index (BMI) and PE. ${ }^{13,14,19}$ One study indicated lower percentage of smoking in the PE group when compared with normal controls $(p=0.028){ }^{13}$

Different methodologies were used to analyze cfDNA. Poon et $\mathrm{al}^{17}$ used chromosome sequencing in the first trimester and Rolnik et al ${ }^{19}$ used targeted chromosome sequencing polymorphism-dependent method for samples collected in first and second trimesters. There were no significant differences found in the study conducted by Poon et al ${ }^{17}$ when the analyses were adjusted for maternal weight, race, and smoking.

The prospective case-control study conducted by Rolnik et $\mathrm{al}^{19}$ assessed cases of "early-PE" (who delivered before 34 weeks) and "late-PE" (who delivered after 34 weeks), which were screened for total cfDNA and cffDNA levels in the first and second trimesters. Despite the fact that high median total cfDNA levels were observed in first trimester screening in the early-PE group $(p<0.05)$, the multiple of the median (MoM) values were not significant after multivariate analysis was performed. In the late-PE group, no significant differences were found for total cfDNA or cffDNA levels for either absolute or MoM values at first and second trimester screening (-Table 1). 
Table 1 Characteristics, sample size, and p-values of the eight included articles

\begin{tabular}{|c|c|c|c|c|c|c|}
\hline \multirow[t]{3}{*}{ Authors } & \multirow{3}{*}{$\begin{array}{l}\text { Gestational } \\
\text { age (wk) }\end{array}$} & \multicolumn{4}{|l|}{ cfDNA levels } & \multirow[t]{3}{*}{$p$-Value } \\
\hline & & \multicolumn{3}{|l|}{ PE } & \multirow[t]{2}{*}{ Controls } & \\
\hline & & All PE & Early onset PE & Late onset PE & & \\
\hline $\begin{array}{l}\text { Papantoniou } \\
\text { et al }^{13}\end{array}$ & $11-13$ & $9,402^{c}$ & - & - & $2,698^{c}$ & 0.000 \\
\hline \multirow[t]{2}{*}{ Kim et al ${ }^{14}$} & $6-14$ & $\begin{array}{l}7,169.6^{\mathrm{b}} \\
(4,895.2-12,384.1)\end{array}$ & \multirow[t]{2}{*}{-} & \multirow[t]{2}{*}{-} & $\begin{array}{l}5,188.1^{\mathrm{b}} \\
(2,042.6-7,682.5)\end{array}$ & $<0.05$ \\
\hline & $15-23$ & $\begin{array}{l}11,262.4^{\mathrm{b}} \\
(9,416.3-16,781.1)\end{array}$ & & & $\begin{array}{l}8,505.4^{\mathrm{b}} \\
(5,794.7-11,479.2)\end{array}$ & $<0.05$ \\
\hline Farina et al $^{15}$ & $20.4 \pm 3.45$ & $439 \pm 299^{a}$ & - & - & $284 \pm 138^{\mathrm{a}}$ & - \\
\hline \multirow[t]{2}{*}{ Silver et al ${ }^{16}$} & \multirow[t]{2}{*}{$9-12$} & 3.52 & \multirow[t]{2}{*}{-} & \multirow[t]{2}{*}{-} & 3.74 & \multirow[t]{2}{*}{0.96} \\
\hline & & $(0.11-25.3)$ & & & $(0.12-21.14)$ & \\
\hline \multirow[t]{2}{*}{ Poon et al $^{17}$} & \multirow[t]{2}{*}{$11-13$} & $138.3^{\mathrm{a}}$ & \multirow[t]{2}{*}{ - } & \multirow[t]{2}{*}{-} & $113.86^{\mathrm{a}}$ & \multirow[t]{2}{*}{$<0.0125$} \\
\hline & & (98.80-200.07) & & & $(98.61-154.84)$ & \\
\hline \multirow[t]{5}{*}{ Salvianti et al $^{18}$} & $6-16$ & $290.41(113-313)^{\mathrm{a}}$ & \multirow[t]{5}{*}{-} & \multirow[t]{5}{*}{-} & $282.07(15-795)^{\mathrm{a}}$ & $<0.05$ \\
\hline & $17-23$ & $769.50(102-1,073)^{a}$ & & & $310.93(71-1,867)^{\mathrm{a}}$ & NS \\
\hline & $24-30$ & $1,262(311-2,330)^{a}$ & & & $295.60(30-825)^{a}$ & $<0.05$ \\
\hline & $31-34$ & $\begin{array}{l}2,830.50 \\
(393-4,163)^{a}\end{array}$ & & & $626.72(143-2,421)^{a}$ & NS \\
\hline & $\geq 35$ & $2,172.00^{\mathrm{a}}$ & & & $532.50(54-2,245)^{\mathrm{a}}$ & NS \\
\hline Rolnik et al ${ }^{19}$ & $\begin{array}{l}11-13 \\
20-24\end{array}$ & - & $\begin{array}{l}2,104^{\mathrm{a}} \\
(1,454-3,547) \\
-\end{array}$ & $\begin{array}{l}2,178^{\mathrm{a}} \\
(1,123-2,847) \\
2,140^{\mathrm{a}} \\
(1,067-2,934)\end{array}$ & $\begin{array}{l}1,590^{\mathrm{a}}(1,111-2,312) \\
1,746^{\mathrm{a}}(1,162-2,311)\end{array}$ & $\begin{array}{l}<0.025 \\
\text { NS }\end{array}$ \\
\hline \multirow[t]{3}{*}{ Kim et $\mathrm{al}^{20}$} & $7-14$ & $26,289.1 \pm 8,923.9^{b}$ & & & $4,007.2 \pm 537.1^{b}$ & $<0.001$ \\
\hline & $15-28$ & $7,962.3 \pm 2,529.9^{b}$ & & & $3,254.2 \pm 287.7^{b}$ & 0.01 \\
\hline & $29-41$ & $41,206.8 \pm 6,488.2^{b}$ & & & $8,771.2 \pm 681.5^{b}$ & $<0.001$ \\
\hline
\end{tabular}

Abbreviations: AUC, area under the curve; cfDNA, cell-free deoxyribonucleic acid; NS, no significance; n/a, not applicable (chromosome sequencing methodology does not use epigenetic markers); PE, preeclampsia; SD, standard deviation.

${ }^{\mathrm{a}} \mathrm{GE} / \mathrm{mL}$.

${ }^{\mathrm{b}}$ Copies/mL.

${ }^{\mathrm{c}} \mathrm{gEq} / \mathrm{mL}$; no median or SD was mentioned, just boxplot and AUC curve.

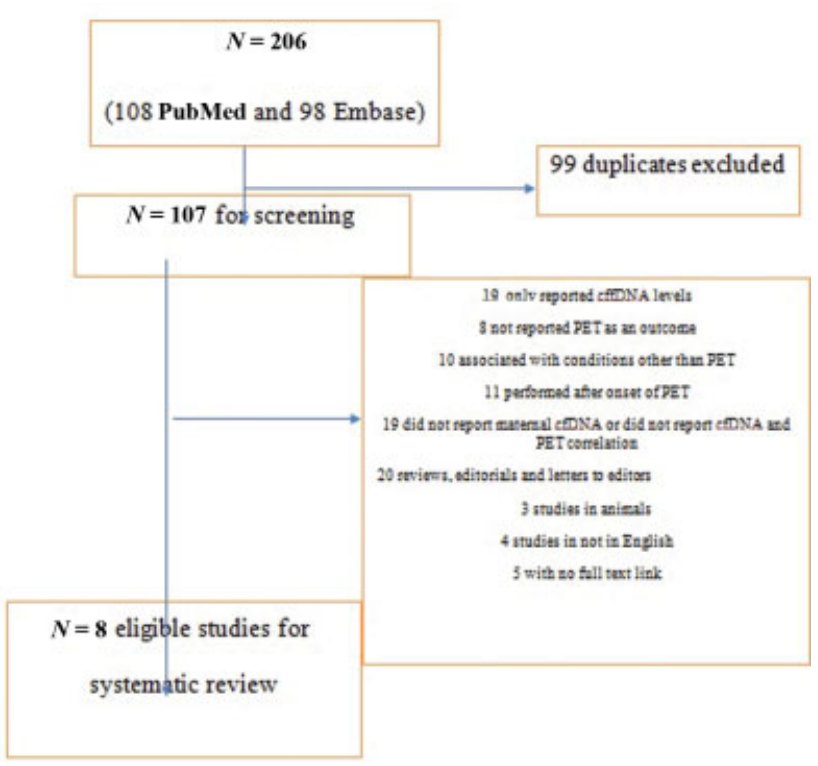

Fig. 1 Flowchart of study review and selection (PRISMA).
Six studies analyzed cfDNA levels by real-time polymerase chain reaction (PCR), using different epigenetic markers to identify the maternal and fetal fractions. ${ }^{13-16,18,20}$ RASSF1A was used in five of six studies as a marker of cffDNA. ${ }^{13,14,16,18,20}$ Five of six studies found significantly higher median levels of cfDNA in the first trimester of patients who developed PE when compared with healthy controls. $^{13-15,18,20}$ Silver et al ${ }^{16}$ conducted a prospective multicenter double-blinded randomized case-control trial and found no significant correlation between cfDNA levels of women who developed PE and controls $(p=0.96)$.

When evaluating total cfDNA levels in maternal circulation in the second trimester, five studies presented increased total cfDNA levels in PE group compared with healthy controls. ${ }^{14,15,18-20}$ Salvianti et al ${ }^{18}$ demonstrated a significant increase of total cfDNA concentrations in maternal plasma in the late second trimester, from 24 to 30 weeks; however, they did not find the same results at 17 to 23 weeks.

Four of the eight included studies showed a longitudinal design evaluating cfDNA and cffDNA levels among different gestational ages. ${ }^{14,18-20}$ Arrows were used to represent the 
Total Cell-Free DNA Wu et al. e41

Table 2 The individual study methodology

\begin{tabular}{|c|c|c|c|c|c|c|}
\hline Authors & $\begin{array}{l}\text { Laboratory methodology } \\
\text { (epigenetic marker) }\end{array}$ & Design & $\begin{array}{l}\text { Cases } \\
\text { (number) }\end{array}$ & $\begin{array}{l}\text { Control } \\
\text { (number) }\end{array}$ & p-Value & Grade \\
\hline Papantoniou et al $^{13}$ & qRT-PCR (RASSF1A) & $\mathrm{RCC}$ & 24 & 48 & 0.000 & $\mathrm{C}$ \\
\hline Kim et al $^{14}$ & Real-time PCR (HYP2) & PCC & 34 & 84 & $<0.05$ & $\mathrm{C}$ \\
\hline Farina et $\mathrm{al}^{15}$ & Real-time PCR ( $\beta$-Globin) & PCC & 8 & 40 & $>0.05$ & $C$ \\
\hline Silver et al $^{16}$ & Real-time PCR (三-actin) & PCCR & 175 & 175 & $>0.05$ & C \\
\hline Poon et al ${ }^{17}$ & Chromosome-selective sequencing (n/a) & RCC & 46 & 1,805 & $<0.0125$ & $\mathrm{C}$ \\
\hline Salvianti et al ${ }^{18}$ & qPCR (RASSF1A) & PCC & 21 & 73 & $<0.05^{\mathrm{a}}$ & C \\
\hline Rolnik et al ${ }^{19}$ & $\begin{array}{l}\text { Targeted sequencing } \\
\text { polymorphism-dependent method (n/a) }\end{array}$ & PCC & 40 & 200 & $<0.025^{\mathrm{b}}$ & $\mathrm{C}$ \\
\hline Kim et $\mathrm{al}^{20}$ & Real time PCR (RASSF1A) & PCC & 29 & 229 & $<0.01$ & $C$ \\
\hline
\end{tabular}

Abbreviations: PCC, prospective case-control study; PCR, polymerase chain reaction; PCCR, prospective case-control study with retrospective analysis, double-blinded; PE, preeclampsia; RCC, retrospective case-control study.

aSalvianti et al showed $p$-value $<0.05$ at 6 to 16 wk and 24 to $30 \mathrm{wk}$.

${ }^{\mathrm{b}}$ Rolnik et al showed $p$-value $<0.025$ only for early onset PE vs. control.

Table 3 Maternal demographic characteristics

\begin{tabular}{|c|c|c|c|c|c|c|c|c|c|c|}
\hline \multirow[t]{2}{*}{ Authors } & \multicolumn{2}{|l|}{ Maternal age $(y)$} & \multicolumn{2}{|l|}{ BMI $\left(\mathrm{kg} / \mathrm{m}^{2}\right)$} & \multicolumn{2}{|c|}{ Nulliparous (\%) } & \multicolumn{2}{|c|}{ Smoking (\%) } & \multicolumn{2}{|c|}{$\begin{array}{l}\text { Family history } \\
\text { of mother with } \\
\text { PE (\%) }\end{array}$} \\
\hline & Cases & Controls & Cases & Controls & Cases & Controls & Cases & Controls & Cases & controls \\
\hline $\begin{array}{l}\text { Papantoniou } \\
\text { et al }{ }^{13}\end{array}$ & $\begin{array}{l}32.9 \\
(28.8-37.3)\end{array}$ & $\begin{array}{l}32.2 \\
(28.8-37.3)\end{array}$ & $\begin{array}{l}27.9^{a} \\
(23.4-32.9)\end{array}$ & $\begin{array}{l}24.8 \\
(22.5-26.2)\end{array}$ & $91.6^{\mathrm{b}}$ & 60.4 & $50^{c}$ & 73 & 0 & 0 \\
\hline Kim et $\mathrm{al}^{14}$ & $\begin{array}{l}34.1 \\
(32.7-36.0)\end{array}$ & $\begin{array}{l}33 \\
(31.0-35.3)\end{array}$ & $\begin{array}{l}22.3^{d} \\
(20.3-23.6)\end{array}$ & $\begin{array}{l}20.2 \\
(18.7-21.7)\end{array}$ & 73.5 & 54.8 & 0 & 0 & $\mathrm{n} / \mathrm{a}$ & $\mathrm{n} / \mathrm{a}$ \\
\hline Farina et al $^{15}$ & $30.5 \pm 5.03$ & $33.5 \pm 2.49$ & - & - & - & - & - & - & - & - \\
\hline Silver et al ${ }^{16}$ & $22.5 \pm 4.4$ & $22.7 \pm 4.4$ & $28.3 \pm 6.9^{d}$ & $25.0 \pm 5.2^{d}$ & - & - & 16 & 23.4 & - & - \\
\hline Poon et al ${ }^{17}$ & $\begin{array}{l}29.7 \\
(24.8-33.6)\end{array}$ & $\begin{array}{l}31.9 \\
(27.8-35.4)\end{array}$ & - & - & - & - & 5.8 & 2.2 & - & - \\
\hline Salvianti et al ${ }^{18}$ & 34 & 32 & 21 & 22.04 & - & - & - & - & 23 & - \\
\hline \multirow[t]{2}{*}{ Rolnik et al ${ }^{19}$} & $\begin{array}{l}(11-13 w k) \\
29.3(23.5-34.6)\end{array}$ & \multirow[t]{2}{*}{$\begin{array}{l}31.6 \\
(28.8-35.4)\end{array}$} & $\begin{array}{l}29.8^{d} \\
(24.4-35.2)\end{array}$ & $\begin{array}{l}24.1 \\
(21.5-27.9)\end{array}$ & $70^{d}$ & \multirow[t]{2}{*}{$\begin{array}{l}40.5 \\
40.5\end{array}$} & 5 & \multirow[t]{2}{*}{$\begin{array}{l}6 \\
6\end{array}$} & 15 & \multirow[t]{2}{*}{$\begin{array}{l}5.5 \\
5.5\end{array}$} \\
\hline & $\begin{array}{l}(20-24 w k) \\
32(29.6-33.3)\end{array}$ & & $\begin{array}{l}31.5^{d} \\
(25.2-34.4)\end{array}$ & $\begin{array}{l}25.7 \\
(22.6-29.1)\end{array}$ & 50 & & 10 & & 5 & \\
\hline Kim et $\mathrm{al}^{20}$ & $34.3 \pm 3.9$ & $32.8 \pm 3.7$ & $25.8 \pm 4.2^{\mathrm{a}}$ & $20.6 \pm 3.0^{a}$ & 36.3 & 41.0 & - & - & - & - \\
\hline
\end{tabular}

Abbreviations: BMI, body mass index; PCR, polymerase chain reaction; PE, preeclampsia; SD, standard deviation.

${ }^{a} p=0.0001$.

${ }^{\mathrm{b}} \mathrm{p}=0.013$.

${ }^{c} p=0.028$.

dStatistically significant difference between cases and controls.

Note: Maternal age and body mass index (BMI) were described with Median \pm SD or mean.

variation trend ( - Table 4 ). We found that total cfDNA was detected earlier in pregnancy when compared with cffDNA. Kim et $\mathrm{al}^{14}$ observed total cfDNA levels were increased as early as 6 to 14 weeks, as well as 15 to 23 weeks in patients who subsequently developed PE.

Kim et $\mathrm{al}^{14}$ used the different markers to evaluate levels of cfDNA and cffDNA in both the first and second trimesters. They found that median levels of total cfDNA when associated with marker HYP2 gene were significantly increased at 6 to 14 and 15 to 23 weeks' gestation for PE, as well as the MoM values were significantly different than the controls. However, the median levels and MoM values of cffDNA when associated with markers DSCR3 and RASSF1A genes at 6 to 14 and 15 to 23 weeks were not significantly different in the PE group during the first or second trimester when compared with controls.

\section{Discussion}

This literature review identified eight studies that investigated the association between cfDNA levels and PE. Most studies showed similar results, demonstrating that median levels of total cfDNA were higher in patients who subsequently developed PE. ${ }^{13-15,17-20}$ Our results point out that 
Table 4 Time points of levels of cfDNA and cffDNA in four studies focusing on different gestational ages

\begin{tabular}{|c|c|c|c|c|}
\hline Authors & $\begin{array}{l}\text { Gestational } \\
\text { age (wk) }\end{array}$ & $\begin{array}{l}\text { cfDNA } \\
\text { level }\end{array}$ & $\begin{array}{l}\text { cffDNA } \\
\text { level }\end{array}$ & $\begin{array}{l}\text { Epigenetic } \\
\text { marker }\end{array}$ \\
\hline $\begin{array}{l}\text { Kim } \\
\text { et al }\end{array}$ & $\begin{array}{l}6-14 \\
15-23\end{array}$ & $\begin{array}{l}\uparrow \\
\uparrow\end{array}$ & $\begin{array}{l}\text { NS } \\
\text { NS }\end{array}$ & $\begin{array}{l}H Y P 2, D S C R 3 \\
\text { and RASSF1A }\end{array}$ \\
\hline \multirow{5}{*}{$\begin{array}{l}\text { Salvianti } \\
\text { et al }\end{array}$} & $6-16$ & $\uparrow$ & NS & \multirow[t]{5}{*}{ RASSF1A } \\
\hline & $17-23$ & NS & NS & \\
\hline & $24-30$ & $\uparrow$ & $\uparrow$ & \\
\hline & $31-34$ & NS & NS & \\
\hline & $\geq 35$ & NS & NS & \\
\hline \multirow{2}{*}{$\begin{array}{l}\text { Rolnik } \\
\text { et }^{1 l^{19}}\end{array}$} & $11-13$ & $\uparrow$ & $\downarrow$ & \multirow[t]{2}{*}{$\mathrm{a}$} \\
\hline & $20-24$ & NS & $\downarrow$ & \\
\hline \multirow{3}{*}{${\text { et } \mathrm{al}^{20}}$} & $7-14$ & $\uparrow$ & NS & \multirow[t]{3}{*}{ RASSF1A } \\
\hline & $15-28$ & $\uparrow$ & $\bar{\uparrow}$ & \\
\hline & $29-41$ & $\uparrow$ & $\uparrow$ & \\
\hline
\end{tabular}

Abbreviations: cfDNA, cell-free deoxyribonucleic acid; cffDNA, cell-free fetal deoxyribonucleic acid; NS, no significance.

a Rolnik et a ${ }^{24}$ determined cfDNA and cffDNA levels using targeted sequencing polymorphism-dependent method. Hence, there is no marker used in this study.

there could be a correlation between high levels of total cfDNA in the first trimester and subsequently developed early PE (before 34 weeks) ${ }^{13,17-20}$ and late PE (after 34 weeks). ${ }^{14,20}$ One study showed correlation between high levels of total cfDNA and development of severe PE. ${ }^{15}$ One study showed no significant difference of total cfDNA concentrations between PE patients and healthy controls. ${ }^{16} \mathrm{We}$ believe that inconsistent results could be explained by different testing methods used to extract cfDNA.

Several maternal demographic factors associated with PE were identified. Silver et $\mathrm{al}^{16}$ showed a mild correlation between high BMI and levels of total cfDNA, and this was statistically significant even when adjusted by race. However, they did not find a significant association between cfDNA and development of PE. Smoking is known to impair placentation and stimulate trophoblastic death, therefore increasing levels of cfDNA. ${ }^{17}$ Two studies in our review found statistically higher median levels among Afro-Caribbean women when compared with Caucasian. ${ }^{17,19}$ The reason behind this fact is unclear.

This review identified several advantages of screening with cfDNA over cffDNA. First, cfDNA measurements are comparatively homogeneous, primarily tested by sequencing, ${ }^{21,22}$ as opposed to the measurements of cffDNA which are highly heterogeneous (including various methods and diverse genes representing cffDNA levels). ${ }^{7,9,14,19,23,24}$ Second, unlike cffDNA testing which needs to be determined by additional methods, such as real-time PCR or methylation modification, cfDNA levels can be measured simultaneously with noninvasive prenatal testing in the first trimester. ${ }^{25,26}$ Third, it is not genderdependent, unlike the cffDNA testing that needs to focus on the Y-specific sequences, such as DYS14 or SRY. ${ }^{6-8,10,27,28}$

A sensitive and noninvasive test that could identify women with high risk of PE early in pregnancy would have a significant impact in obstetric management. It would offer an opportunity to introduce prophylactic measures to selected patients, as well as increase clinical surveillance, and potentially reduce maternal-fetal morbidity and mortality. We believe that cfDNA could be a reliable noninvasive marker of $\mathrm{PE}$ when screened in the first trimester. However, more randomized controlled trials are needed to prove this association.

\section{Limitations}

The limitations of this review must be acknowledged. First, we were unable to perform a thorough analysis of the different results and meta-analysis as there was significant methodological heterogeneity between studies, with objectives comparing different fractions of DNA analyzed by either PCR or biochemical markers. Second, demographic confounding factors were not always adjusted for, and there were relatively small sample sizes in the PE groups. Further research within larger populations, controlled for demographic bias, with standardized methodology and similar gestational age gaps should be performed to draw more consistent conclusions.

\section{Conclusion}

In conclusion, this is a review concerning the potential association between total cfDNA and cffDNA in early identification of patients who are at high risk of subsequent PE. Data from current literature suggest that total cfDNA levels in maternal circulation could be used as a predictive marker for early detection of PE.

\section{Author's Contributions}

Y.W. and A.W. contributed equally for the development of this paper and should be considered first authors. Y.W., A.L., and M.W. developed the research question and protocol for this study. Y.W. wrote the first draft and extracted the data. A.W. critically reviewed, rewrote, and revised the manuscript. Y.W., A.W., and M.W. have primary responsibility for the final content. All authors provided feedback on the read and approved the final manuscript.

\section{Funding}

This study was supported by CIHR (Canadian Institutes of Health Research), Grant Number FDN-148438.

\section{Conflict of Interest}

The authors declare no conflict of interest.

\section{Acknowledgments}

We would like to thank Katherine Muldoon and Malia Murphy at the Ontario Health Research Institute (OHRI) for her ongoing input and expertise, as well as Kara BellaiDussault for providing additional clinical rationale.

\section{References}

1 Sibai B, Dekker G, Kupferminc M. Pre-eclampsia. Lancet 2005;365 (9461):785-799 
2 Umesawa M, Kobashi G. Epidemiology of hypertensive disorders in pregnancy: prevalence, risk factors, predictors and prognosis. Hypertens Res 2017;40(03):213-220

3 Duley L. The global impact of pre-eclampsia and eclampsia. Semin Perinatol 2009;33(03):130-137

4 Contro E, Bernabini D, Farina A. Cell-free fetal DNA for the prediction of pre-eclampsia at the first and second trimesters: a systematic review and meta-analysis. Mol Diagn Ther 2017;21 (02):125-135

5 Zeisler H, Llurba E, Chantraine F, et al. Predictive value of the sFlt1:PlGF ratio in women with suspected preeclampsia. N Engl J Med 2016;374(01):13-22

6 Lo YMD, Leung TN, Tein MSC, et al. Quantitative abnormalities of fetal DNA in maternal serum in preeclampsia. Clin Chem 1999;45 (02):184-188

7 Vlkova B, Turna J, Celec P. Fetal DNA in maternal plasma in preeclamptic pregnancies. Hypertens Pregnancy 2015;34(01): 36-49

8 Martin A, Krishna I, Badell M, Samuel A. Can the quantity of cellfree fetal DNA predict preeclampsia: a systematic review. Prenat Diagn 2014;34(07):685-691

9 Leung TN, Zhang J, Lau TK, Chan LYS, Lo YMD. Increased maternal plasma fetal DNA concentrations in women who eventually develop preeclampsia. Clin Chem 2001;47(01):137-139

10 Lo YMD, Corbetta N, Chamberlain PF, et al. Presence of fetal DNA in maternal plasma and serum. Lancet 1997;350(9076):485-487

11 Miranda ML, Macher HC, Muñoz-Hernández R, et al. Role of circulating cell-free DNA levels in patients with severe preeclampsia and HELLP syndrome. Am J Hypertens 2013;26(12): 1377-1380

12 Guyatt GH, Oxman AD, Vist GE, et al. GRADE: An emerging consensus on rating quality of evidence and strength of recommendations. Chin J Evid-Based Med 2009;9(01):8-11

13 Papantoniou N, Bagiokos V, Agiannitopoulos K, et al. RASSF1 A in maternal plasma as a molecular marker of preeclampsia. Prenat Diagn 2013;33(07):682-687

14 Kim SY, Kim HJ, Park SY, Han YJ, Choi JS, Ryu HM. Early prediction of hypertensive disorders of pregnancy using cell-free fetal DNA, cell-free total DNA, and biochemical markers. Fetal Diagn Ther 2016;40(04):255-262

15 Farina A, Sekizawa A, Iwasaki M, Matsuoka R, Ichizuka K, Okai T. Total cell-free DNA ( $\beta$-globin gene) distribution in maternal plasma at the second trimester: a new prospective for preeclampsia screening. Prenat Diagn 2004;24(09):722-726
16 Silver RM, Myatt L, Hauth JC, et al. Cell-free total and fetal DNA in first trimester maternal serum and subsequent development of preeclampsia. Am J Perinatol 2017;34(02):191-198

17 Poon LCY, Musci T, Song K, Syngelaki A, Nicolaides KH. Maternal plasma cell-free fetal and maternal DNA at 11-13 weeks' gestation: relation to fetal and maternal characteristics and pregnancy outcomes. Fetal Diagn Ther 2013;33(04):215-223

18 Salvianti F, Inversetti A, Smid M, et al. Prospective evaluation of RASSF1A cell-free DNA as a biomarker of pre-eclampsia. Placenta 2015;36(09):996-1001

19 Rolnik DL, O'Gorman N, Fiolna M, van den Boom D, Nicolaides KH, Poon LC. Maternal plasma cell-free DNA in the prediction of preeclampsia. Ultrasound Obstet Gynecol 2015;45(01):106-111

20 Kim MJ, Kim SY, Park SY, Ahn HK, Chung JH, Ryu HM. Association of fetal-derived hypermethylated RASSF1A concentration in placenta-mediated pregnancy complications. Placenta 2013;34(01): 57-61

21 Brady P, Brison N, Van Den Bogaert K, et al. Clinical implementation of NIPT-technical and biological challenges. Clin Genet 2016;89(05):523-530

22 Wong FCK, Lo YMD. Prenatal diagnosis innovation: genome sequencing of maternal plasma. Annu Rev Med 2016;67:419-432

23 Kim HJ, Kim SY, Lim JH, Kwak DW, Park SY, Ryu HM. Quantification and application of potential epigenetic markers in maternal plasma of pregnancies with hypertensive disorders. Int J Mol Sci 2015;16(12):29875-29888

24 Levine RJ, Qian C, Leshane ES, et al. Two-stage elevation of cell-free fetal DNA in maternal sera before onset of preeclampsia. Am J Obstet Gynecol 2004;190(03):707-713

25 Gil MM, Accurti V, Santacruz B, Plana MN, Nicolaides KH. Analysis of cell-free DNA in maternal blood in screening for aneuploidies: updated meta-analysis. Ultrasound Obstet Gynecol 2017;50(03): 302-314

26 Taylor-Phillips S, Freeman K, Geppert J, et al. Accuracy of noninvasive prenatal testing using cell-free DNA for detection of Down, Edwards and Patau syndromes: a systematic review and meta-analysis. BMJ Open 2016;6(01):e010002

27 Zhong XY, Holzgreve W, Hahn S. The levels of circulatory cell free fetal DNA in maternal plasma are elevated prior to the onset of preeclampsia. Hypertens Pregnancy 2002;21(01):77-83

28 Cotter AM, Martin CM, O'leary JJ, Daly SF. Increased fetal DNA in the maternal circulation in early pregnancy is associated with an increased risk of preeclampsia. Am J Obstet Gynecol 2004;191 (02):515-520 


\section{Appendix 1}

1. qStudies that only reported cffDNA levels without cell-free deoxyribonucleic levels were excluded.

1. Zhong XY, Holzgreve W, Hahn S. The levels of circulatory cell-free fetal DNA in maternal plasma are elevated prior to the onset of preeclampsia. Hypertens Pregnancy 2002;21(1):77-83.

2. Levine RJ, Qian C, Leshane ES, Yu KF, England LJ, Schisterman EF, Wataganara T, Romero R, Bianchi DW. Two-stage elevation of cell-free fetal DNA in maternal sera before onset of preeclampsia. Am J Obstet Gynecol. 2004;190(3):707-713.

3. Thurik FF, Lamain-de Ruiter M, Javadi A, Kwee A, Woortmeijer H, Page-Christiaens GC, Franx A, van der Schoot CE, Koster MP. Absolute first trimester cell-free DNA levels and their associations with adverse pregnancy outcomes. 2016;36 (12):1104-1111.

4. Yu H, Shen Y, Ge Q, He Y, Qiao D, Ren M, Zhang J. Quantification of maternal serum cell-free fetal DNA in early-onset preeclampsia. Int J Mol Sci 2013;14(4):7571-7582

5. Kaufmann I, Rusterholz C, Hösli I, Hahn S, Lapaire O. Can detection of late-onset PE at triage by sflt-1 or PlGF be improved by the use of additional biomarkers? Prenat Diagn 2012;32(13):1288-1294

6. Kimura C, Watanabe K, Iwasaki A, Mori T, Matsushita H, Shinohara K, Wakatsuki A. The severity of hypoxic changes and oxidative DNA damage in the placenta of early-onset preeclamptic women and fetal growth restriction. J Matern Fetal Neonatal Med 2013;26(5):491-496.

7. Stein W, Müller S, Gutensohn K, Emons G, Legler T. Cell-free fetal DNA and adverse outcome in low risk pregnancies. Eur J Obstet Gynecol Reprod Biol 2013;166(1):10-13.

8. Alberry MS, Maddocks DG, Hadi MA, Metawi H, Hunt LP, Abdel-Fattah SA, Avent ND, Soothill PW. Quantification of cell free fetal DNA in maternal plasma in normal pregnancies and in pregnancies with placental dysfunction. Am J Obstet Gynecol 2009;200(1):98.e1-6.

9. Bauer M, Hutterer G, Eder M, Majer S, Leshane E, Johnson KL, Peter I, Bianchi DW, Pertl B. A prospective analysis of cell-free fetal DNA concentration in maternal plasma as an indicator for adverse pregnancy outcome. Prenat Diagn 2006;26 (9):831-836.

10. Diesch CH, Holzgreve W, Hahn S, Zhong XY. Comparison of activin A and cell-free fetal DNA levels in maternal plasma from patients at high risk for preeclampsia. Prenat Diagn 2006;26(13):1267-1270.

11. Li Y, Zhong XY, Kang A, Troeger C, Holzgreve W, Hahn S. Inability to detect cell free fetal DNA in the urine of normal pregnant women nor in those affected by preeclampsia associated HELLP syndrome. J Soc Gynecol Investig 2003;10 (8):503-518.

12. Manokhina I, Singh TK, Robinson WP. Cell-free placental DNA in maternal plasma in relation to placental health and function. Fetal Diagn Ther 2017;41(4):258-264.

13. Shimada K, Murakami K, Shozu M, Segawa T, Sumitani H, Inoue M. Sex-determining region Y levels in maternal plasma: evaluation in abnormal pregnancy. J Obstet Gynaecol Res 2004;30(2):148-154.

14. Wataganara T1, Chen AY, LeShane ES, Sullivan LM, Borgatta L, Bianchi DW, Johnson KL. Cell-free fetal DNA levels in maternal plasma after elective first-trimester termination of pregnancy. Fertil Steril 2004;81(3):638-644.

15. Wataganara T, Metzenbauer M, Peter I, Johnson KL, Bianchi DW. Placental volume, as measured by 3-dimensional sonography and levels of maternal plasma cell-free fetal DNA. Am J Obstet Gynecol 2005;193(2):496-500.

16. Zimmermann BG, Maddocks DG, Avent ND. Quantification of circulatory fetal DNA in the plasma of pregnant women. Methods Mol Biol 2008;444:219-229.

17. Farina A, Sekizawa A, Rizzo N, Concu M, Banzola I, Carinci P, Simonazzi G, Okai T. Cell-free fetal DNA (SRY locus) concentration in maternal plasma is directly correlated to the time elapsed from the onset of preeclampsia to the collection of blood. Prenat Diagn 2004;24(4):293-297.

18. Farina A, Sekizawa A, Sugito Y, Iwasaki M, Jimbo M, Saito H, Okai T. Fetal DNA in maternal plasma as a screening variable for preeclampsia. A preliminary nonparametric analysis of detection rate in low-risk nonsymptomatic patients. Prenat Diagn 2004;24(2):83-86.

19. Sifakis S, Zaravinos A, Maiz N, Spandidos DA, Nicolaides KH. First-trimester maternal plasma cell-free fetal DNA and preeclampsia. Am J Obstet Gynecol 2009;201(5):472.e1-477.

2. Studies focusing on pregnancy-associated complications other than preeclampsia were excluded (IUGR, stillbirth, preterm birth, etc.).

1. Yoshida A, Watanabe K, Iwasaki A, Kimura C, Matsushita H, Wakatsuki A. Placental oxidative stress and maternal endothelial function in pregnant women with normotensive fetal growth restriction. J Matern Fetal Neonatal Med 2017;3:1-7.

2. Egan K, Kevane B, Ní Áinle F. Elevated venous thromboembolism risk in preeclampsia: molecular mechanisms and clinical impact. Biochem Soc Trans 2015;43(4):696-701. 
3. Prasad V. Non-invasive, serum DNA pregnancy testing leading to incidental discovery of cancer: a good thing? Eur J Cancer 2015;51(16):2272-2274.

4. Korabecna M, Ulcova-Gallova Z, Horinek A, Pazourková E, Calda P. Quantification of circulating fetal DNA as a tool for potential monitoring of pregnant patients with antiphospholipid antibodies. Autoimmunity 2014;47(7):473-477.

5. Caramelli E1, Rizzo N, Concu M, Simonazzi G, Carinci P, Bondavalli C, Bovicelli L, Farina A. Cell-free fetal DNA concentration in plasma of patients with abnormal uterine artery Doppler waveform and intrauterine growth restriction-a pilot study. Prenat Diagn 2003;23(5):367-371.

6. Marazzi MC, Liotta G, Nielsen-Saines K, Haswell J, Magid NA, Buonomo E, Scarcella P, Doro Altan AM, Mancinelli S, Palombi L. Extended antenatal antiretroviral use correlates with improved infant outcomes throughout the first year of life. AIDS 2010;24(18):2819-2826.

7. Sekizawa A, Jimbo M, Saito H, Iwasaki M, Matsuoka R, Okai T, Farina A. Cell-free fetal DNA in the plasma of pregnant women with severe fetal growth restriction. Am J Obstet Gynecol 2003;188(2):480-484.

8. Zhong XY, Steinborn A, Sohn C, Holzgreve W, Hahn S. High levels of circulatory erythroblasts and cell-free DNA prior to intrauterine fetal death. Prenat Diagn 2006;26(13):1272-1273.

3. Studies reporting on cell-free deoxyribonucleic level but focusing on other pathogenic conditions (such as aneuploidy, methylation, or autoimmune disease) instead of pregnancy-associated complications were excluded.

1. Bianchi DW. Should we "open the kimono" to release the results of rare autosomal aneuploidies following noninvasive prenatal whole genome sequencing? Prenat Diagn 2017;37(2):123-125.

2. Rahat B, Thakur S, Bagga R, Kaur J. Epigenetic regulation of STAT5A and its role as fetal DNA epigenetic marker during placental development and dysfunction. Placenta 2016;44:46-53.

3. Ma KK, Rodriguez MI, Cheng YW, Norton ME, Caughey AB. Should cell-free DNA testing be used to target antenatal rhesus immune globulin administration? J Matern Fetal Neonatal Med 2016;29(11):1866-1870.

4. Kalafat E, Seval MM, Turgay B, Koç A. Non-invasive prenatal testing for sex chromosome abnormalities: a source of confusion. BMJ Case Rep 2015;2015:bcr2014207309.

5. Morris S, Karlsen S, Chung N, Hill M, Chitty LS. Model-based analysis of costs and outcomes of non-invasive prenatal testing for Down's syndrome using cell free fetal DNA in the UK National Health Service. PLoS One 2014;9(4):e93559.

6. Hill M, Taffinder S, Chitty LS, Morris S. Incremental cost of non-invasive prenatal diagnosis versus invasive prenatal diagnosis of fetal sex in England. Prenat Diagn 2011;31(3):267-273.

7. Zhong XY, Wang Y, Chen S, Labu, Pubuzhuoma, Gesangzhuogab, Ouzhuwangmu, Hahn C, Holzgreve W, Hahn S. Can circulatory fetal DNA be used to study placentation at high altitude? Ann N Y Acad Sci 2004;1022:124-128.

8. Hahn S, Zhong XY, Bürk MR, Troeger C, Kang A, Holzgreve W. Both maternal and fetal cell-free DNA in plasma fluctuate. Ann N Y Acad Sci 2001;945:141-144.

9. Vora NL, Johnson KL, Lambert-Messerlian G, Tighiouart H, Peter I, Urato AC, Bianchi DW. Relationships between cell-free DNA and serum analytes in the first and second trimesters of pregnancy. Obstet Gynecol 2010;116(3):673-678.

10. Krishna I, Badell M, Loucks TL, Lindsay M, Samuel A. Adverse perinatal outcomes are more frequent in pregnancies with a low fetal fraction result on noninvasive prenatal testing. Prenat Diagn 2016;36(3):210-215.

4. Studies reporting on the cell-free deoxyribonucleic values after the clinical onset of preeclampsia were excluded.

1. Lo YM, Leung TN, Tein MS, Sargent IL, Zhang J, Lau TK, Haines CJ, Redman CW. Quantitative abnormalities of fetal DNA in maternal serum in preeclampsia. Clin Chem 1999;45(2):184-188.

2. Kim HJ, Kim SY, Lim JH, Kwak DW, Park SY, Ryu HM. Quantification and application of potential epigenetic markers in maternal plasma of pregnancies with hypertensive disorders. Int J Mol Sci 2015; 16(12):29875-29888.

3. AbdelHalim RM, Ramadan DI, Zeyada R, Nasr AS, Mandour IA. Circulating maternal total cell-free DNA, cell-free fetal DNA and soluble endoglin levels in preeclampsia: predictors of adverse fetal outcome? A cohort study. Mol Diagn Ther 2016;20 (2):135-149.

4. Qi YH, Teng F, Zhou Q, Liu YX, Wu JF, Yu SS, Zhang X, Ma MY, Zhou N2, Chen LJ. Unmethylated-maspin DNA in maternal plasma is associated with severe preeclampsia. Acta Obstet Gynecol Scand 2015;94(9):983-988.

5. Swinkels DW, de Kok JB, Hendriks JC, Wiegerinck E, Zusterzeel PL, Steegers EA. Hemolysis, elevated liver enzymes, and low platelet count (HELLP) syndrome as a complication of preeclampsia in pregnant women increases the amount of cell-free fetal and maternal DNA in maternal plasma and serum. Clin Chem 2002;48(4):650-653.

6. Lazar L, Rigó J Jr, Nagy B, Balogh K, Makó V, Cervenak L, Mézes M, Prohászka Z, Molvarec A. Relationship of circulating cellfree DNA levels to cell-free fetal DNA levels, clinical characteristics and laboratory parameters in preeclampsia. BMC Med Genet 2009;10:120.

7. Sekizawa A, Farina A, Koide K, Iwasaki M, Honma S, Ichizuka K, Saito H, Okai T. $\beta$-globin DNA in maternal plasma as a molecular marker of pre-eclampsia. Prenat Diagn 2004;24(9):697-700. 
8. Zeybek YG, Günel T, Benian A, Aydınlı K, Kaleli S. Clinical evaluations of cell-free fetal DNA quantities in pre-eclamptic pregnancies. J Obstet Gynaecol Res 2013;39(3):632-640.

9. Zhao F, Wang J, Liu R, Yang J, Cui K, Wu Y, Guo J, Mu Y, Wang X. Quantification and application of the placental epigenetic signature of the RASSF1A gene in maternal plasma. Prenat Diagn. 2010;30(8):778-782.

10. Zhong XY, Holzgreve W, Hahn S. Circulatory fetal and maternal DNA in pregnancies at risk and those affected by preeclampsia. Ann N Y Acad Sci 2001;945:138-140.

11. Muñoz-Hernández R, Medrano-Campillo P, Miranda ML, Macher HC, Praena-Fernández JM, Vallejo-Vaz AJ, DominguezSimeon MJ, Moreno-Luna R, Stiefel P. Total and fetal circulating cell-free DNA, angiogenic, and antiangiogenic factors in preeclampsia and HELLP syndrome. Am J Hypertens 2017;30(7):673-682.

5. Studies focusing on preeclampsia or hypertensive disease but did not report the maternal cell-free deoxyribonucleic (DNA) levels, or did not address the correlation between maternal cell-free DNA and preeclampsia, were excluded.

1. Li N, Fu Y, Chen W, Hu GQ, Zhou M, Yu SX, Zhang XJ, Du CT, Yang YJ. IFI16 mediates soluble Flt-1 and endoglin production by trophoblast cells. J Hypertens 2015;33(8):1658-1665.

2. Fleischhacker M. The 2nd International Symposium on circulating nucleic acids in plasma and serum (CNAPS-2), Hong Kong, February 20-21, 2001. Eur J Med Res 2001;6(8):364-368.

3. Hung TH, Lo LM, Chiu TH, Li MJ, Yeh YL, Chen SF, Hsieh TT. A longitudinal study of oxidative stress and antioxidant status in women with uncomplicated pregnancies throughout gestation. Reprod Sci 2010;17(4):401-409.

4. Huppertz B, Kingdom JC. Apoptosis in the trophoblast-role of apoptosis in placental morphogenesis. J Soc Gynecol Investig 2004;11(6):353-362.

5. Molvarec A, Rigó J Jr, Lázár L, Balogh K, Makó V, Cervenak L, Mézes M, Prohászka Z. Increased serum heat-shock protein 70 levels reflect systemic inflammation, oxidative stress and hepatocellular injury in preeclampsia. Cell Stress Chaperones 2009;14(2):151-159.

6. Molvarec A, Szarka A, Walentin S, Szucs E, Nagy B, Rigó J Jr. Circulating angiogenic factors determined by electrochemiluminescence immunoassay in relation to the clinical features and laboratory parameters in women with preeclampsia. Hypertens Res 2010;33(9):892-898.

7. Reddy A, Zhong XY, Rusterholz C, Hahn S, Holzgreve W, Redman CW, Sargent IL. The effect of labor and placental separation on the shedding of syncytiotrophoblast microparticles, cell-free DNA and mRNA in normal pregnancy and pre-eclampsia. 2008;29(11):949-949.

8. Sahin H, Gunel T, Benian A, Onay Ucar E, Guralp O, Kilic A. Genomic and proteomic investigation of preeclampsia. Exp Ther Med 2015;10(2):711-716.

9. Sekizawa A, Yokokawa K, Sugito Y, Iwasaki M, Yukimoto Y, Ichizuka K, Saito H, Okai T. Evaluation of bidirectional transfer of plasma DNA through placenta. Hum Genet 2003;113(4):307-310.

10. Stenczer B1, Rigó J Jr, Prohászka Z, Derzsy Z, Lázár L, Makó V, Cervenak L, Balogh K, Mézes M, Karádi I, Molvarec A. Plasma osteopontin concentrations in preeclampsia-is there an association with endothelial injury? Clin Chem Laboratory Med 2010;48(2):181-187.

11. Szarka A, Rigó J Jr, Lázár L, Beko G, Molvarec A. Circulating cytokines, chemokines and adhesion molecules in normal pregnancy and preeclampsia determined by multiplex suspension array. BMC Immunol 2010;11:59.

12. Thway TM, Shlykov SG, Day MC, Sanborn BM, Gilstrap LC 3rd, Xia Y, Kellems RE. Antibodies from preeclamptic patients stimulate increased intracellular $\mathrm{Ca}^{2+}$ mobilization through angiotensin receptor activation. Circulation 2004;110 (12):1612-1619.

13. Tjoa ML1, Oudejans CB, van Vugt JM, Blankenstein MA, van Wijk IJ. Markers for presymptomatic prediction of preeclampsia and intrauterine growth restriction. Hypertens Pregnancy 2004;23(2):171-189.

14. Zhang J, Christianson RE, Torfs CP. Fetal trisomy 21 and maternal preeclampsia. Epidemiology 2004;15(2):195-201.

15. Zhong XY, Holzgreve W, Hahn S. Cell-free fetal DNA in the maternal circulation does not stem from the transplacental passage of fetal erythroblasts. Mol Hum Reprod 2002;8(9):864-870.

16. Zhong XY, Laivuori H, Livingston JC, Ylikorkala O, Sibai BM, Holzgreve W, Hahn S. Elevation of both maternal and fetal extracellular circulating deoxyribonucleic acid concentrations in the plasma of pregnant women with preeclampsia. Am J Obstet Gynecol 2001;184(3):414-419.

17. Gupta A, Hasler P, Gebhardt S, Holzgreve W, Hahn S. Occurrence of neutrophil extracellular DNA traps (NETs) in preeclampsia: a link with elevated levels of cell-free DNA? Ann N Y Acad Sci 2006;1075:118-122.

18. Gupta AK, Hasler P, Holzgreve W, Hahn S. Neutrophil NETs: a novel contributor to preeclampsia-associated placental hypoxia? Semin Immunopathol 2007;29(2):163-167.

19. Palma C, Zamora C, González M, Gallardo V. PP131. Regulation of heme oxygenase/carbon monoxide (ho/co) and 1-arginine/nitric oxide (no) pathways by human chorionic gonadotropin (hcg) in human fetal endothelium. Pregnancy Hypertens 2012;2(3):309-310. 
6. For this paper, although they evaluated the cell-free deoxyribonucleic levels in non pregnancy, normal pregnancy, and preeclampsia (PE) patient, they did not give the p-value between PE and normal pregnancy. They gave out the figure of comparison between normal nonpregnancy and PE. Hence, excluded.

1. Sur Chowdhury C, Hahn S, Hasler P, Hoesli I, Lapaire O, Giaglis S. Elevated levels of total cell-free DNA in maternal serum samples arise from the generation of neutrophil extracellular traps. Fetal Diagn Ther 2016;40(4):263-267.

7. Reviews, editorials, and letters to editors were all excluded.

1. Sonek JD, Kagan KO, Nicolaides KH. Inverted pyramid of care. Clin Laboratory Med 2016;36(2):305-317.

2. Cuckle H, Maymon R. Development of prenatal screening-a historical overview. Semin Perinatol 2016;40(1):12-22.

3. Park HJ, Shim SS, Cha DH. Combined screening for early detection of pre-eclampsia. Int J Mol Sci 2015;16(8):17952-17974.

4. Vlková B1, Turňa J, Celec P. Fetal DNA in maternal plasma in preeclamptic pregnancies. Hypertens Pregnancy 2015;34 (1):36-49.

5. Martin A1, Krishna I, Badell M, Samuel A. Can the quantity of cell-free fetal DNA predict preeclampsia: a systematic review. Prenat Diagn 2014;34(7):685-691.

6. Hahn S, Giaglis S, Buser A, Hoesli I, Lapaire O, Hasler P. Cell-free nucleic acids in (maternal) blood: any relevance to (reproductive) immunologists? J Reprod Immunol 2014;104-105:26-31.

7. Taglauer ES, Wilkins-Haug L, Bianchi DW. Review: cell-free fetal DNA in the maternal circulation as an indication of placental health and disease. Placenta 2014;35 suppl:S64-S68.

8. Krantz D, Hallahan T, Janik D, Carmichael J. Maternal serum screening markers and adverse outcome: a new perspective. J Clin Med 2014;3(3):693-712.

9. Cuckle H. Prenatal screening using maternal markers. J Clin Med 2014;3(2):504-520.

10. Hahn S, Rusterholz C, Hösli I, Lapaire O. Cell-free nucleic acids as potential markers for preeclampsia. Placenta 2011;32 suppl:S17-S20.

11. Bianchi DW. Circulating fetal DNA: its origin and diagnostic potential-a review. Placenta 2004;25 suppl A:S93-S101.

12. Gammill HS, Nelson JL. Naturally acquired microchimerism. Int J Dev Biol 2010;54(2-3):531-543.

13. Hahn S, Chitty LS. Noninvasive prenatal diagnosis: current practice and future perspectives. Curr Opin Obstet Gynecol 2008;20(2):146-151.

14. Hahn S, Huppertz B, Holzgreve W. Fetal cells and cell free fetal nucleic acids in maternal blood: new tools to study abnormal placentation? Placenta 2005;26(7):515-526.

15. Litton C1, Stone J, Eddleman K, Lee MJ. Noninvasive prenatal diagnosis: past, present, and future. Mt Sinai J Med 2009;76 (6):521-528.

16. Lo YM. Fetal DNA in maternal plasma. Ann N Y Acad Sci 2000;906:141-147.

17. Wataganara T, Bianchi DW. Fetal cell-free nucleic acids in the maternal circulation: new clinical applications. Ann N Y Acad Sci 2004;1022:90-99.

18. Gammill HS, Aydelotte TM, Guthrie KA, Nkwopara EC, Nelson JL. Cellular fetal microchimerism in preeclampsia. Hypertension 2013;62(6):1062-1067.

19. Halmos A, Rigó J Jr, Szijártó J, Füst G, Prohászka Z, Molvarec A. Circulating ficolin-2 and ficolin-3 in normal pregnancy and pre-eclampsia. Clin Exp Immunol 2012;169(1):49-56.

20. Krantz DA, Hallahan TW, Carmichael JB. Screening for open neural tube defects. Clin Laboratory Med 2016;36(2):401-406.

\section{Studies not concerning human were excluded.}

1. Čonka J, Konečná B, Lauková L, Vlková B, Celec P2. Fetal DNA does not induce preeclampsia-like symptoms when delivered in late pregnancy in the mouse. Placenta 2017;52:100-105. (rats)

2. Konečná B, Borbélyová V, Celec P, Vlková B. Does rat fetal DNA induce preeclampsia in pregnant rats? J Dev Orig Health Dis. 2015;6(1):5-9.

3. Konečná B, Sysák R, Kacerovský M, Celec P, Vlková B. Deoxyribonuclease activity in plasma of pregnant women and experimental animals. J Matern Fetal Neonatal Med 2017;22:1-3.

\section{Studies that were not English language were excluded.}

1. Guibourdenche J1, Leguy MC, Tsatsaris V. Biology and markers of preeclampsia [in French]. Ann Biol Clin (Paris) 2013;71:79-87.

2. Yan JY1, Xu X. Relationships between concentrations of free fatty acid in serum and oxidative-damage levels in placental mitochondria and preeclampsia [in Chinese]. Zhonghua Fu Chan Ke Za Zhi 2012;47(6):412-417.

3. Rijnders RJ1, Christiaens GC, de Haas M, van der Schoot CE. Fetal DNA in maternal blood [in Dutch]. Ned Tijdschr Geneeskd 2004;148(4):170-174.

4. Lázár L1, Nagy B, Molvarec A, Rigó JJr. Quantity of total cell free and cell free fetal DNA in pregnancies with no complications and with preeclampsia [in Hungarian]. Orv Hetil 2010;151(19):784-787. 
e48 Total Cell-Free DNA Wu et al.

10. Studies without full text linkage were excluded.

1. Seval MM, Karabulut HG, Tükün A, Koç A. Cell free fetal DNA in the plasma of pregnant women with preeclampsia. Clin Exp Obstet Gynecol 2015;42(6):787-791.

2. Hahn S, Holzgreve W. Fetal cells and cell-free fetal DNA in maternal blood: new insights into pre-eclampsia. Hum Reprod Update 2002;8(6):501-508.

3. Holzgreve W, Hahn S. Prenatal diagnosis using fetal cells and free fetal DNA in maternal blood. Clin Perinatol 2001;28 (2):353-365.

4. Holzgreve W, Hahn S. Fetal cells in cervical mucus and maternal blood. Baillieres Best Pract Res Clin Obstet Gynaecol 2000;14(4):709-722.

5. Holzgreve W, Zhong XY, Burk MR, Hahn S. Enrichment of fetal cells and free fetal DNA from maternal blood: an insight into the Basel experience. Early Pregnancy 2001;5(1):43-44. 